\begin{tabular}{c} 
Volume and Issues Obtainable at Center for Sustainability Research and Consultancy \\
Journal of Business and Social Review in Emerging Economies \\
ISSN: 2519-089X (E): 2519-0326 \\
Volume 6: No. 1, March 2020 \\
CSRᄃ \\
Journal homepage: www.publishing.globalcsrc.org/jbsee \\
\hline
\end{tabular}

\title{
The Role of Social Class on Consumer Behavior: A Study of Eco-friendly Cosmetic Products
}

\author{
${ }^{1}$ Shaheera Amin, ${ }^{2}$ Aaliya Manzoor, ${ }^{3}$ Fatima Farid \\ ${ }^{1}$ Department of Business Administration, University of Sahiwal, Pakistan: shaheera.ac@gmail.com \\ ${ }^{2}$ Department of Business Administration, University of Sahiwal, Pakistan \\ ${ }^{3}$ Department of Business Administration, University of Sahiwal, Pakistan
}

\begin{tabular}{l} 
ARTICLE DETAILS \\
\hline History \\
Revised format: February 2020 \\
Available Online: March 2020
\end{tabular}

\section{Keywords}

Ecofriendly Cosmetics,

Consumers' Behavior,

Consumers' Value, Buying

Behavior

\section{JEL Classification:}

L66, O2

\begin{abstract}
In the past few decades, the analysts have noticed an important change in consumers' behavior while purchasing and picking products, especially in cosmetics. Now, when consumers purchase the product, they pay more attention to health and environment features of the product. Therefore, the purpose of this research is to analyze Pakistani Consumers' buying behavior towards EcoFriendly Cosmetic products. The theory of planned behavior has been applied for better understanding of consumer behavior. Moreover, analyzed the relationship of consumers' values on their intention to buy eco-friendly cosmetics products. It is studied that consumers' social class has a moderating effect on consumer's intention toward purchasing eco-friendly cosmetic products. For quantitative data collection questionnaire is constructed. For questionnaire, variable scales are adapted from literature. Convenience sampling is used for distribution of questionnaire. Data is composed from 260 respondents in Punjab, Pakistan. For analyzing the data, statistical analysis will be done by using SPSS and AMOS. All variables are significantly influence consumer intention to purchase eco-friendly cosmetics. This research suggests marketers to develop their marketing strategies and promote ecofriendly cosmetics through effective advertising.
\end{abstract}

(C) 2020 The authors, under a Creative Commons AttributionNonCommercial 4.0

Corresponding author's email address: shaheera.ac@gmail.com

Recommended citation: Amin, S., Manzoor, A., \& Farid, F. (2020). The Role of Social Class on Consumer Behavior: A Study of Eco-friendly Cosmetic Products. Journal of Business and Social Review in Emerging Economies, 6(1), 113-134

DOI: $10.26710 /$ jbsee.v6i1.1032

\section{Introduction}

The concern related environment has developed very essential issues all around the world (Laheri-et, 2014). People always listen that the China and USA meetings to minimize greenhouse gas, which releases fail. Iranian cheetahs, Siberian tiger and Chinese pandas are injured. Because the layer of ozone is split and the melting and warming speed of ice is increase day by day. People hear this type of news many 
times. Additionally, the reduction of natural resources, change in climate, pollution in air and waste generation are the chief environmental difficulties that the policies deal with. Over the previous years, much struggle has been made into policies intend manufacture processes. Universal heating is become a major reason of environmental concern. Moreover, in few years, values of individual consumption outlook are emphasized, because up level of products usage endangers the nature on environment, the preparation of maintainable progression and development (Liu al., 2010; Tukker al., 2010; Liobikien, Dagiliut, 2016). Environmental consciousness behavior, consumer health and appearance have encouraged consumers to purchase eco-friendly and other beautifying products (Schlegelmilch Et Al, 1996; Newsom al, 2005; Peattie, 2001; TOD, 2004, Paladino, 2006).

Consciousness toward natural resources raised the topic of the environmental protection that turn the term of green consumerism also called "Eco-friendly consumer behavior" (Moisander, 2007). The term ecofriendly addresses other terms like: environmentally friendly, green or environmentally responsible activities and sustainable (Han al, 2009, 2011; Roberts, 1996; Laroche Et al, 2001; Pizam, 2009). If want to minimize the effects of consumption on environment it is compulsory to advertise the consumption of eco-friendly products. Consumers awareness or concern toward environment firmly determine consumers to purchase green and eco-friendly cosmetics (Kim, Seock, 2009; Kim, Chung, 2011; Pervin al., 2014; Tamashiro, 2014; Patel al., 2015; Hsu al., 2017). So, numerous businesses have improved their operational procedure and manufacturing process (Taghian, and D'Souza, 2005). When marketer directs the marketing strategy consumer behavior is most important thing to elaborate (Han and Kim, 2010). To predict consumer behavior, it is important to understand consumer purchase intentions. This is the responsibility of individuals to initiate step to save the environment because environmental protection is the social responsibility. Usage of eco-friendly products also a step which individual take to save the environment.

\subsection{Problem Statement}

In developing countries yet there is absence of consumer recognition, understanding and utilization of eco-friendly products between consumers' (Kumar, Ali, 2011). Further the ingredients and chemicals which use in cosmetics are very dangerous for skin and human body. Moreover, the testing of these products on animal is also not ethical. So, this is very important to turn consumer intention toward ecofriendly products. According to (Mont, Plepys, 2008; Elliott al, 2013; Ritter al., 2015) the consumption of ecofriendly products minimizes the bad impacts on environment.

\subsection{Objective of the Research}

Now a day the noteworthy expansion of eco-friendly products among people in Pakistan has created massive suggestions for main industry, especially, cosmetics industry. Therefore, the primary aim of this research is to examine the Pakistani consumers purchasing behavior toward ecofriendly cosmetic products. The purpose of this study is to explore the factors which influence consumer behavior to purchase eco-friendly products. Further planned behavior theory investigates consumers' attitude and their purchase intention toward ecofriendly cosmetic products. This theory is an extended form of theory of reasoned action (Ajzen, 1991). Moreover, this research considers consumer values as an antecedent of consumer's intention to purchase. Additionally, the moderating influence of social class intention to purchase relationship is judged. Thus, this research provides an understanding toward buying pattern of consumers for eco-friendly cosmetics.

\subsection{Significance of the Study}

Products production process and the utilization of these products are very harmful to the environment because now some days the reduction of natural resources is very important issue which governments and peoples face. This is very important to save our natural resources and the environment. Moreover, the Government of Pakistan also take an initiative step toward clean the environment. One aspect to save the environment is the consumption of eco-friendly products. The consumption of ecofriendly products minimizes the bad impacts on environment. Customers also try to use that type products which are not 
harm full for their skin and body also. But the high price is the issue for people to purchase that type of products but consumer who have luxury lifestyle there is no issue for that type of people to purchase ecofriendly products. That's why in this research add the variable of social class as a moderator and check its influence toward consumer intention to purchase toward eco-friendly cosmetics. So, the findings of this research helpful for marketers, to decide which segment they target. This research finding tells that to target the segment, considers the consumer class is very important for marketers. Eco-friendly products are costly as compared to conventional products, so this is important for marketers when they choose the segment.

\subsection{Research Gap}

Over previous decade eco-friendly products or industry attain much intentions of consumers and researchers also. Now consumers are more conscious regarding their environment. Further consumers are also conscious about the usage of products either that product is eco-friendly or not. Few researches (Sharmila, Devi 2016; Suki, 2016; Liobikiene, 2016) focused on the concept of eco-friendly products and enhance the literature of eco-friendly products. Moreover (Sharmila; 2016) discuss the gender difference and the behaviour of consumer toward eco-friendly products. But this study fills the gap of (Asad and Naveed, 2017) research. According to Naveed, 2017 consumer lifestyle is very important for consumer to purchase eco-friendly products. In this study add the variable of consumer social class and family and friends to know how consumer social class is important for consumer to purchase eco-friendly goods or cosmetics. Because lifestyle is important part of consumer social class so try to fill this gap and use social class (lifestyle and family and friends) as a moderating variable.

\subsection{Research Questions}

Research question of this study are:

- Do consumers' values (Health consciousness, Environmental consciousness and ethical consumerism) influence consumers' behavior to buy eco-friendly cosmetics?

- What is the impact of consumer social class (lifestyle, family and friends) on consumer behavior to buy eco-friendly cosmetics?

\section{Literature Review and Model Development}

\subsection{Consumers Values}

Values have many definitions which occurs in different context. According to (Zeithaml et al, 1988, p. 14) value is "the consumer overall assessment of the utility of a product based on perception of what is received and what is given". According to Psychologist value interpret our belief about preferable end states (Feather et al, 1990; Schwartz and Blisky, 1987; Rokeach, 1973). This research prospect that people which have distinct value mean they present diverse behavior towards eco-friendly cosmetics because different consumers have different standards or goals in their lives (Rokeach al, 1973). Beliefs or Values may be influenced the individual or buyers attitude and guide to observe the object which satisfies their beliefs and values (Poortinga al, 2004; Grunert and Juhi 1995). According to literature of organic food and green products; values matter with consumer health and environmental attitude toward purchasing the organic (Chrysohoidis al and Krystallis 2005). Hence this study initiated three values of consumer which effects individual intentions toward purchasing the eco-friendly cosmetics: health consciousness andconsciousness toward environment plus ethical consumerism. These three values are very important in term of purchasing the eco-friendly products or cosmetics. These three terms are influence consumers to purchase eco-friendly cosmetics.

\subsubsection{Health Consciousness}

Initially consciousness regarding their health directs consumers to involve in healthy behavior (Becker al., 1977). Today many people are health consciousness and supervise their desired states, so put an effort toward retaining a fit or healthy life (Newsom al., 2005). High amount related to the environment, concern is predicted because of health-related issues or concerns (Said, 2003). Health consciousness indicates the desire of individuals to start active and healthy actions (Chen, 2010). Consumers who are 
health consciousness are focused towards their healthy life and the activities which related to the health of individuals. These types of individuals are very conscious to their mental and physical health (Kraft, 1993). According to (Michaelidou, 2008) consumers who are health conscious are very alert and concerned regarding their health plus interested to increase the life quality and maintain the fitness of their body. In this way, they avoid the disorder or confusion by getting to the healthy attitude further they remain self-conscious regarding their health. Moreover (Jayanti,1998) define that the health consciousness is a mark in which anxiety related to the health are integrated towards individual's life and other day by day related actions. Magnusson (2001) define that the wellbeing is just as the component of superiority and this is important to make decision to purchase or not purchase the products. Results of many research studies tell that the consumer anxiety related to the health is the main reason sometime to pick organic food (Schifferstein, 1998).

Different consumers are different type of concerns regarding their health. When consumers purchase the cosmetics, they keenly observed that the cosmetics are safe for skin as compare to those individuals who have below level of urge regarding health consciousness (Johri andSahasakmontri et al, 1998). When consumers supervise their health, they keenly observe healthy cosmetics (Media,2008). Belief regarding safety of product and the product friendless into environment effects pro environmental consumer behavior (Judhi and Ahmad, 2008). Further Judhi and Ahmad (2008) illustrate that the perception about organic food influence pro- environmental consumer behavior. According to Chung and Kim (2011) consciousness toward health is the much significant factor which influence consumer attitude regarding organic cosmetics.

The health-related aspects of organic, green and eco-friendly utilization is ordinary affiliated with the non-existence of chemicals, like pesticides and the chemical-form fertilizers which consume in agriculture (Xie al., 2015). Numerous consumers believe that the organic products like food are healthier and safer than traditional products. Because these types of products are free from chemicals and pesticides (Wier al., 2008). According to Magnusson et al. (2003) consumers concern regarding their family and personal health, is the more significant factor which influence consumer attitude related organic apparels and food. Several studies present that the major factors which motivate women's related purchase of green or ecofriendly cosmetics and personal care products are animal welfare, concern toward environment and health issues (Zanoli al, Naspetti al, 2002; Diamantopoulos Et., 2003; Tsakiridou, 2008; Paladino et, 2006; Peter, Olson, 2009; Cervellon et., 2010).

H1: Health consciousness firmly influences consumer's intention to buy eco-friendly cosmetics.

\subsubsection{Environmental Consciousness}

Environmental conciseness can be defined as "a wide-ranging knowledge of realities, ideas, and associations regarding the normal environment and its key ecosystems" (Fryxell al, 2003). Cosmetics are the material which utilize to improve the appearance of individuals body or skin (Rawat et, Garga, 2012; Pervin al., 2014; Patel, 2015). Present cosmetic industries utilize a variety of chemicals like petrochemicals, parabens, sodium sulphate and artificial colors. The utilization of these chemicals in a long period of time; may be the source of many health problems like cancer, allergies and dermatitis. Nijkamp (2015) stated that the cosmetics and the other related products contribute toward general exposures of consumers' more than domiciliary cleaning agents. Moreover, consumers withdraw the unwanted exposures toward preservations. Ingredients which are synthetic, bioengineering products, hormones and the pesticides are much probable to utilized eco-friendly or green cosmetics. Thus, green or eco-friendly cosmetics demand will be increased surprisingly (Ferrer et al., 2012). The organic cosmetic market had been increasing per year (20\%) in Europe (Organics Monitors, 2011). The principal requirement for eco-friendly, green, organic cosmetics is that the components should be eco-friendly means that components magnifying without pesticides, toxic material, synthetic fertilizer, organisms which are modified genetically and the ionizing radiation. 
According to several findings people awareness toward environment is important for green utilization (Dembkowski al, 1998; Mintu-Wimsatt and Polonsky, 1995). Environment save responsibility is significant determinant of individual behavior regarding eco-friendly products (Paladino, 2005). Consumers' pro ethical or the pro social behaviors is affected by age of people (Panni al, 2006) moreover young people are much conscious related to environment problems than old people (Coddington, 1993; Memery al., 2005, D’Souza al., 2007).

H2: Environmental consciousness firmly influences consumer intentions to buy eco-friendly cosmetics.

\subsubsection{Ethical Consumerism}

Finally, Ethical consumerism is also very important element of consumer behavior toward eco-friendly cosmetics. Many researcher results mention that females pay extra or higher prices to ethical licensed goods (Mather al., 2005). Several authors also argued that ethical attitude of consumer, hardly influence consumers for ethical buying behavior. (Devinney; Auger, 2007; Laroche al.2002). Many consumers show their positive attitude toward companies which are using environmental practices (Han, Kim, 2010; Olsen al, 2014). This inconsistency between buying pattern and attitude due to absence of these products unbelief regarding ethical assertion and absence of trust and information (Tsakiridou al, 2008; Cervellon,2010). Retaining good quality product will provide satisfaction to customers and additionally generate customer loyalty (Chumpitaz el and Paparoidamis, 2004; Kotler al., 2005). Further related ecological perspective, eco-friendly or green consumers recognize that the eco-friendly, organic and green cosmetics having superior quality and safer for skin and health. Because in these types of products not add the chemicals and other pesticides (McWilliams al and Siegel, 2001; Yiridoe al., 2005; D'Souza al., 2006; Martenson, 2007; Cornelissen et al., 2008; Rios et al., 2006). Now a day's consumer is more aware, so looking for the cosmetics which are not injure human skin as well as animals skin. The Act related cosmetics dated 30th April 2001 declare that the ingredients which used in cosmetics are not damage the human body and maintain care and cleanness of skin (Dz.U. 2001; Ustawa, Kurzępa B; 2009).

Thus, companies want to modify the perception of consumers through informative marketing campaigns which highlight the ethics of humans toward animals and environment. Because many consumers not know about the benefits or significance of eco-friendly goods so this is important for marketers to tell the overall benefits of community when individual use the eco-friendly cosmetics and other eco-friendly goods. (McEachern al, McClean al, 2005; D’Souza al.,2007a, 2007b).

H3: Ethical consumerisms firmly influence consumer intentions to buy eco-friendly cosmetics.

\subsubsection{Lifestyle}

According to Olson and Peter (2009) beauty care and cosmetic products are essential to self-image and lifestyle of females. Because in this current era individual are progressively evaluate about their look rather what he or she do. Moreover, consumer environmental knowledge and knowledge about ecofriendly, organic or green products attestation, is a vital driver for buying that products. Lifestyle of consumer is very important aspect for researchers. In this research briefly explain consumer social class and their life style. Because life style of consumer is generally treated as one of the much significant forecaster regarding human behavior (Thompson al, and Kaminski, 1993; Kucukemiroglu al, 1999; Kaynak and Kara, 2001, 2002; Fraj E and Martinez E, 2006a, 2006b; Ottman A, 2006; Ahmad al., 2010, 2012, 2014; Chanaron al, 2013). Moreover, life style of consumers plays an analytical role through serving as recommendation for consumer behavior and attitude (Yu C, 2011; Chen, 2014). Additionally, consumer preference regarding eco-friendly products or goods is control by the two factors and that are social and psychological (Mostafa al, 2009; Lee et, 2009; Jansson al., 2010; Smith S, Paladino, 2010; Kim $\mathrm{H}$, Chung J, 2011). Additionally, healthy lifestyle or healthy process of life is concerned to an equitable life to which consumer create rational choices which focus particularly on nutrition, alcohol consumption, smoking and exercises. Eco cert (2003) stated that the green cosmetics, eco-friendly cosmetics or the bio cosmetics are observed as those cosmetics which have superior demand, as compare to conventional 
products. Lifestyle or style mention the human behavior, mostly, side of marketing which relates consumer behavior (Zepeda \&Nie, 2011). The importance of consumer's lifestyle is very significant for the stakeholders, because in this way they can shape their marketing strategies based on requirements of their customers' (Lee al., 2009; Orth al, 2012; Ahmad, 2014). Further the study related to consumer lifestyle decrease the cost or price and enhance the profits of adapting people needs and wants (Kaynak al, Kara, 2002; Chen, 2014).

H4: Lifestyle of consumer firmly influence consumer intentions to buy eco-friendly cosmetics.

\subsubsection{Family and Friends}

A broad number of researches revealed that community circumstances "or social sanctions" motivate individuals to buy eco-friendly goods (Lin, Hsu, 2015; Wu and Chen, 2014; Biswas al, Roy al, 2015; Ritter al, 2015; Liobikien al, 2016; Suki al, 2016; and Suki, 2016). Consumers' family includes their parents, sisters and other family members. In family members, there are both males and female's family members. In nature males and females are different in their thinking process their behavior is also different toward purchasing of eco-friendly products. According to (Mather al, 2005) females are always primed to pay extra for ethical licenses of eco-friendly products. Many researchers define that the female consumers are sensitive toward environment or the welfare of animals that why they prefer to purchase that firm products which are engaged in environmental practices (Manaktola and Jauhri, 2007). Women's are very diplomatic related to environment issues and perceive them better than men; that's why more purchase eco-friendly cosmetics and products so become eco-friendly consumer's (Memry, 2005 and DoPaco Al, 2009, Stern al, 1993).

Moreover, Huang and Lin, 2012 have declared that the society or social values did not creates a significant impact on consumer attitude or behavior regarding eco-friendly goods. Social pressure family and friends also encourage consumers to buy ecofriendly products (Zhao Et al, 2014; Lorek al, Fuchs, 2013; Wang Al, 2014; Biswas, Roy, 2015; Ritter Al, 2015; Liobikiene al, 2016, Vermeir al, Verbeke, 2008). According to (Kharim, 2015) lifestyle measure the activities of people like how people expend their time, type of passion they have, importance they want on their surroundings, their comments toward society and themselves also. Social elements like family and friends attitude toward eco-friendly products should influence customer to purchase or not purchase that cosmetics (Moungkhem al, Surakiatpinyo, 2010; Kim al, Chung, 2011; Hsu ET, 2017). Consumer think that the family and friends give consumer a reliable information and trustworthy also. If consumers get more positive information about the product, their behavior is also positive to purchase the product. It is an efficient marketing, for instance, "80\% of all buying decisions are influenced by someone's direct recommendations" (Solomon al. 2010,402).According to (D'Souza al, 2006, p150) consumer previous experience and their family and friends influence consumer to purchase eco-friendly products.

H5: Consumers family and friends firmly influences consumers intention to buy eco-friendly cosmetic products.

\subsection{Social Class as a Moderator}

Consumer social class creates a moderating effect on individual attitude to buy eco-friendly cosmetic products. Consumers belong to different social classes and every social class has different norms. Social norms can be comprehended as the perceived social force to carry out green or eco-friendly purchase behavior (Ajzen, 1991). The indicator of environmentally friendly social norms connected with consumer attitude towards ecofriendly purchasing behavior, and reveal how positive social image is important for consumer (Barber al., 2014). Consumer social class strengths the relationship of consumer values and their intention to buy eco-friendly products. Several, studies define that the women who are politically liberal and their income is also higher with higher education level shows higher responsibility or concern toward environmental safety or protection (Bang B., 2000; Brody al, 2004; Memeryal., 2005; Paladino al, 2006, Do Paço al., 2009 and D’Souza., 2007a, 2007b). 
H6: Consumer social class firmly influence consumer intentions to buy eco-friendly cosmetics

\subsection{Conceptual Framework}

Many previous researchers have selected the model of TPB to analyze behavior intention of consumers (Chen, 2016; Chin al., 2016; Casidy al., 2016 Paul, 2016, 2015). Like Han al (2012) use this model for hotel customers whose intention to visit the green hotel. Moreover previous studies (Kim al., 2013; Moser, 2016; Nguyen et al., 2016; Paul al., 2016) also use this model to analyze the relationship with build, engagement and acceptance of consumer's eco-friendly and ecological behavior. In addition, Tung and Chen (2014) applied TPB model for covered the concern related environment and moral obligation will be perceived to analyze intention of consumers visit to green hotel. Han al (2010) determine that model of TPB is effectively able to analyze individual purchasing intention beside the model of reasoned action theory (TRA). In this study utilize the model of TPB to compute purchase intention of consumers toward ecofriendly cosmetic products.

The current study focuses on eco-friendly cosmetics and checks the consumer values like health consciousness, environmental consciousness and ethical consumerism toward behavior to purchase ecofriendly cosmetics. So, we will rely on study conducted by (Sharmila Pudarut; Thanika Devi Juwaheer 2006). In their study, they check the gender difference and the economic condition of consumers towards intention to purchase eco-friendly cosmetics. Their research conclusion and findings provide us an opportunity to connect to our research questions.

We modified the model presented by (Hee Kim and Jae-Eun, 2011). They also work on consumer values and use theory of planned behavior to check consumer behavior to purchase eco-friendly cosmetics. But in this research modified that model and add some other variables. In this research add social class as a moderator to examine how consumer values influence consumers to purchase eco-friendly cosmetics (see Fig 2.2).

\section{Theoretical Framework}

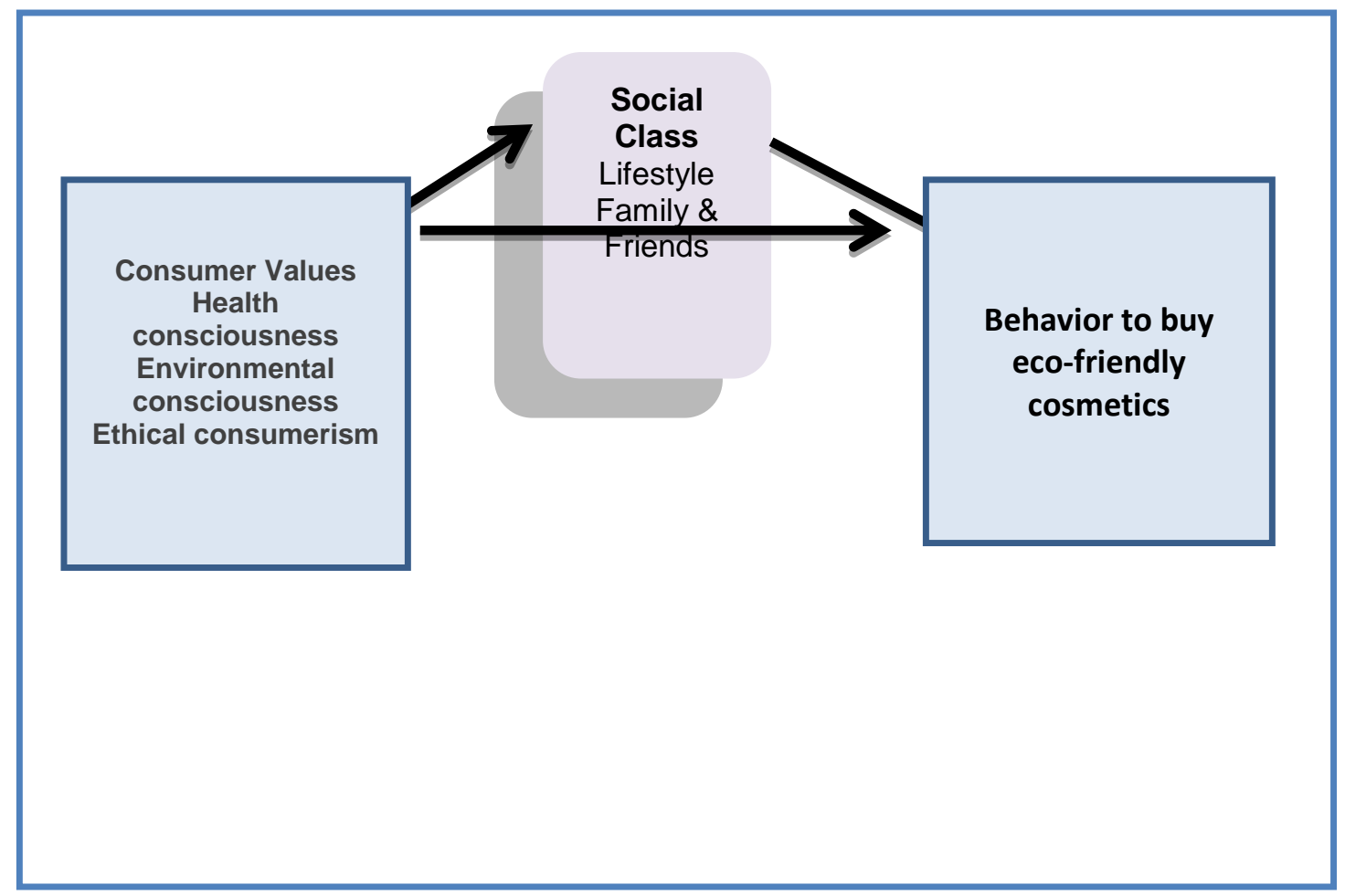




\section{Methodology}

In this research adopt positivism philosophy because in nature this is quantitative research further perspective of reasoning or reinforced the ending which is accessible for observing the community existence and inaugurate legal, reliable data accordingly.

In this research select deductive approach because the researcher generates a chain of hypothesis in research. After this associated research process are choose and inspect hypothesis to verify them right or wrong "www.ukessays.com". Deduction is the major approach of research because in this law present the base of description, enable the phenomena expectation, forecast their existence and enable them to moderate (Collis al, 2003).

This research used mono method because this study applies quantitative research approach. Quantitative method eventually utilizes to examine views, actions, moods etc. Quantitative research "is the collection of data that involves larger, more respondent's samples and numerical calculation of results" (Diggines and Wiid, 2009). Further this research moves from general to specific reasoning and this way originate a top down deductive approach (Bell and Bryman, 2011). By the utilization of quantitative research pattern this study will be perceived some advantages as compare to qualitative one.

Questionnaire is substantially well-ordered method of data collection in which respondent are inspected queries (Mecoll al, 1993). Questionnaire is covering a wider population and allows simple contrast that's why questionnaire will be choosing for this research.

In this research cross sectional study will be used. Cross sectional study builds upon that rumination which appears only once in distinct sections. It conveys not empirical method so, through analyst there is no variable will be managed.

This scrutiny utilizes both procedure of data. To gather the primary data, fill out the questionnaire from respondents and secondary data gathered through past researches and literature. "Multiple articles, books, journals, online resources" this all type of literature was used to enhance the awareness of research.

In this research adopt descriptive research design its utilized to define the distinct attributes of distinct condition. This also defines the behavior regarding population. "www.research-methodology.net".

Table 3.1 Sources of Scale

\begin{tabular}{|l|l|l|}
\hline Scale (variable names) & Items & References \\
\hline Consumer Values & & $\begin{array}{l}\text { Sharmila Pudaruth, Thanika Devi Juwaheer and } \\
\text { Yogini Devi Seewoo (2013) }\end{array}$ \\
\hline (a)Health consciousness & 3 & \\
\hline $\begin{array}{l}\text { (b)Environmental } \\
\text { consciousness }\end{array}$ & 4 & \\
\hline (c)Ethical consumerism & 3 & $\begin{array}{l}\text { Sharmila Pudaruth, Thanika Devi Juwaheer and } \\
\text { Yogini Devi Seewoo (2013) } \\
\text { Hee Yeon Kim and Jae-Eun Chung (2011) }\end{array}$ \\
\hline Social class & & \\
\hline (a)Life style & 3 & \\
\hline (b) Family and Friends & 3 & \\
\hline
\end{tabular}




\begin{tabular}{|l|l|l|}
\hline TPB & & $\begin{array}{l}\text { Jillian J Francis, Martin P Eccles, Marie Johnston, } \\
\text { Anne Walker, } \\
\text { Jeremy Grimshaw, Robbie Foy, Eileen F S Kaner, } \\
\text { Liz Smith, Debbie Bonetti (2004), } \\
\text { GenovaiteLiobikiene, SvitrigailéGrincevičiené, } \\
\text { JurgaBernatoniene (2016), } \\
\text { Sharmila Pudaruth, Thanika Devi Juwaheer and } \\
\text { Yogini Devi Seewoo (2013) }\end{array}$ \\
\hline Attitude & 3 & \\
\hline Subjective Norms & 3 & \\
\hline Perceived behavioral control & 3 & $\begin{array}{l}\text { Sharmila Pudaruth, Thanika Devi Juwaheer and } \\
\text { Yogini Devi Seewoo (2013) } \\
\text { Hee Yeon Kim and Jae-Eun Chung (2011) }\end{array}$ \\
\hline Purchase Intention & 3 &
\end{tabular}

There are many approaches which can be used to determine the suitable sample size. Rule of thumb determine that digit of sample not less than 200 for well-ordered (SEM) structural equation modeling (Kline, 2011). Several researchers suggested that for suitable sample size its significant to comments are between 5, 10 comments to every forecasted parameter, lesser "threshold" level (Hair, 2010). Haier 1998 suggest that " 20 to 40 " comments or feedback about every forecasted parameter.

Against per questionnaire at least five observations or comments and maximal 10 observations. According to instructions $150(39 * 5)$ respondents required. But dispense questionnaire to 261 respondents to indemnify data which is missing.

In this research adopt convenience sampling this is the technique of non-random sampling. This study uses convenience sampling because the sample is choosing which are easily reachable to researcher or analyst. Moreover, this technique is inexpensive, simple and lightly time-consuming. Further convenience sampling has wide acceptance sampling technique because it's found to be more flexible for researchers (Marshall, 1996). Mostly this technique use in social science plus management studies and consider the very effective way to analyze the results.

\section{Data Analysis \& Findings}

\subsection{Reliability Analysis}

Reliability interprets the scale which generate constant outcome whenever the computation are copied in numerous times. Reliability analysis utilizes to calculate the internal stability of scale by Chronbach's $\alpha$. The total reading for all variables of chronbach's described the following table. According to (Haier ET, al 2010) the threshold value was above the 0.70. This indicates that the instruments used in this study were reliable. Hair et al.(1998), stated that if the coefficient is less than 0.6 its indicate that the internal consistency is marginal to low if the value of more than 0.60 its indicate that the internal consistency and the reliability is satisfactory (Churchill, 1979).

Table 4-1 Reliability Analysis

\begin{tabular}{|l|l|l|l|}
\hline Sr. & Variables & Items no. & Chronbach'sAlpha. \\
\hline 1 & Consumer values & & \\
\hline $1(\mathrm{a})$ & Health consciousness & 3 & 0.784 \\
\hline $1(\mathrm{~b})$ & Environmental Consciousness & 4 & 0.799 \\
\hline
\end{tabular}




\begin{tabular}{|l|l|l|l|}
\hline $1(\mathrm{c})$ & Ethical Consumerism & 4 & 0.778 \\
\hline & Social class & 6 & 0.787 \\
\hline & Attitude & 3 & 0.785 \\
\hline & SubjectiveNorms & 3 & 0.793 \\
\hline & Perceived behavioral control & 3 & 0.782 \\
\hline
\end{tabular}

The value of chronbach's for every variable in this research is larger than required limit point. The value of chronbach's for health consciousness, 0.784 , value of environmental consciousness, 0.799 , and value of ethical consumerism, 0.778. Further the value of social class variables is 0.787 , value for attitude is 0.785 , value for subjective norms is 0.793 , value for perceived behavioral control, 0.782 .

\subsection{Construct Validity}

Validity indicates the construct measurement and describes what's the claim and evaluate to measure. (Good win, 2009). After reliability, the next step is to examine the construct validity (Nunally, 1978). Construct validity are two kinds reported that convergent validity and next is discriminant. According to (Haier, Babin, Anderson. Black and Tatham, 2007) analysis of factors is the supreme way to establish validity of construct. To calculate the validity of construct, utilize confirmatory factor analysis (CFA).

\subsubsection{Confirmatory Factor Analysis}

CFA is the technique which utilizes to validate the model factor. CFA also utilized to govern the (MM) measurement model validity (Gerbing and Anderson, 1992). Validity of the measurement model is check through fit indices. To inspect (MM) measurement model validity; fit indices consider the supreme way (Bacharach and Furr, 2013).

\subsubsection{Measurement Model (MM)}

Measurement model utilize to define the fit and goodness of the model (Anderson and Gerbing, 1992). To construct the measurement model used Amos 20.0. The usage of fit indices is to analyze the fitness of $(\mathrm{MM})$. Fit indices measures or estimates may be changed by researcher to researcher and distinct statisticians. Moreover (Kenny and McCoach,2003 and Steen-camp,2003) comments about the fit indices indication through the value of TLI, CFI and RMESA is much appropriate. Further the value of chisquare also illustrates the model fitness. If the value of chi-square is large it shows the poor fitness of model (Bagozzi and Yi, 1998) but if the chi-square value <3, it shows the good fitness of model.

Table 4.1.1 Model Fit Statistics for Measurement Model

\begin{tabular}{|lccccc|}
\hline $\begin{array}{l}\text { Measurement } \\
\text { Model }\end{array}$ & Df $\begin{array}{c}\chi 2 / \mathrm{df} \\
<3>0.95\end{array}$ & CFI & NNFI & RMSEA \\
& & & \\
\hline \\
\hline
\end{tabular}




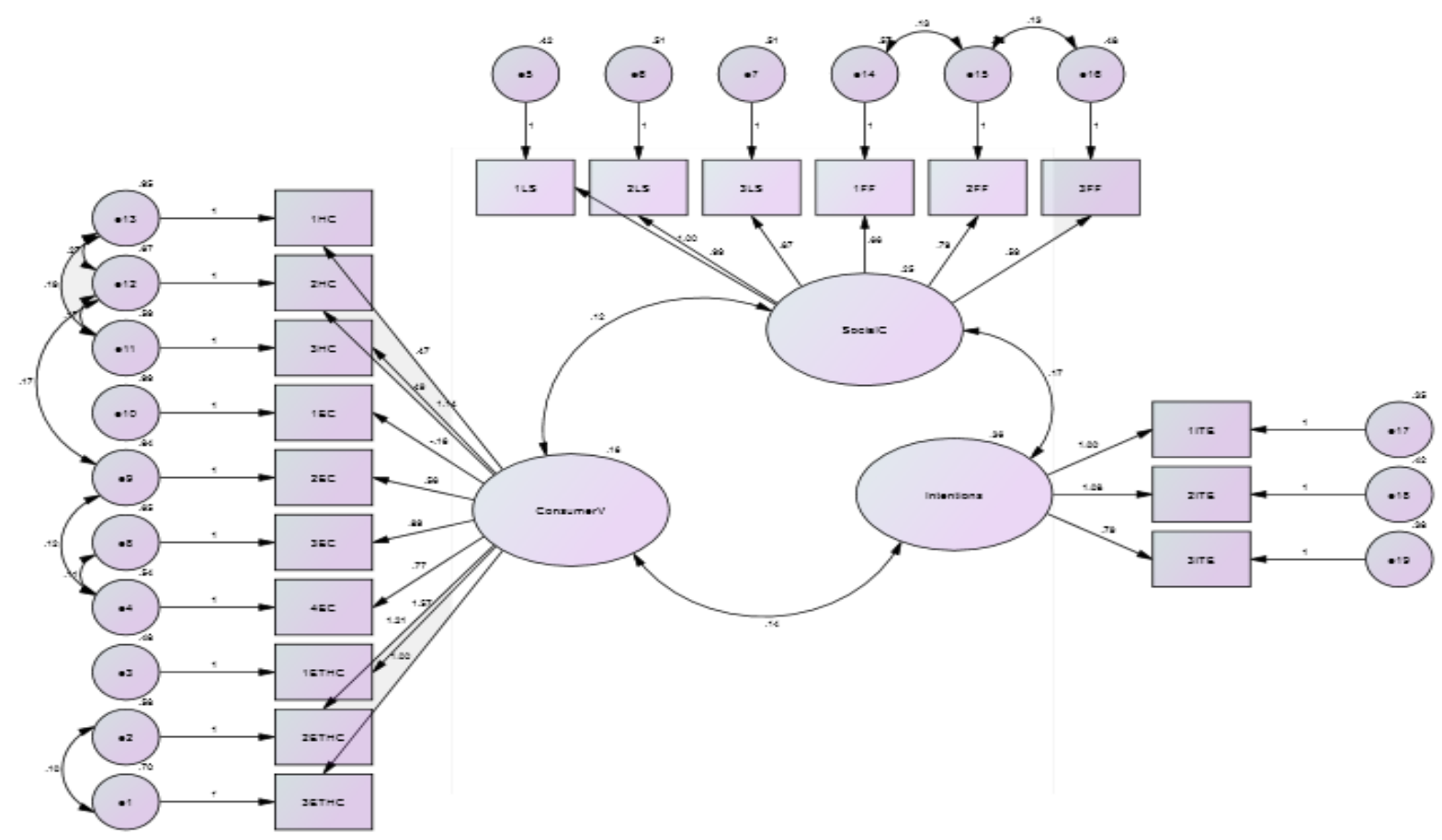

Figure 4.1 Measurement Model

Results which mention in table 8 shows that the, value of chi-square is less than $3(\chi 2=203.771)$ then see the value of $\mathrm{df}(\mathrm{df}=146, \chi 2 / \mathrm{df}=1.456)$. These values show the good fitness of measurement model. CFI (Comparative fit index) is the next step of fit index. Value range of CFI is " 0 to 1 ". If the value of CFI is large it's show the good fitness but if the value of CFFI is small its show the bad fitness of measurement model. According to the results the CFI value of the measurement model is .901 and the suggested value of CFI is $>0.95$. But the value of .90 is also accepted. According to (Cheung and Rensvold, 2002) if the value of CFI is equal 0.90 or the .901 , then the model can obtain additional considerations. Measurement model value of NNFI "non-normed fit index" is less than 0.90 or equal the 0.90 is also accepted. "Root Mean Square Error of approximation" (RMESA) is the succeeding step of fit index. If the value of RMESA of MM is $<0.08$ that shows the good fitness. According to table the RMESA value is .046 which $<0.08$. Further (Bollen, Long, Cudeck and Browne, 1993) indicate that the RMESA value is acceptable if its <0.08. Moreover (MacCallum, Sugarawa and Browne, 1996) indicates that if the value of RMESA value is $0.08,0.05$ and 0.01 it shows the good and excellent fit. Overall results show that the measurement model is good fit.

\subsection{Correlation Analysis}

In this research first predict connection among values and their intention to purchase eco-friendly cosmetics. Results found that the strong and positive correlation with consumer intentions and consumer values like Health consciousness the value of $\mathrm{r}$ is $(\mathrm{r}=.196, \mathrm{p}<0.05)$, environmental consciousness $(\mathrm{r}=$ $.322, \mathrm{p}<0.05)$, ethical consumerism $(\mathrm{r}=.148, \mathrm{p}<0.05)$. Moreover consumer social class is a very a high degree of correlation toward consumer attitude and their intention to purchase eco-friendly cosmetics. In social class consumer lifestyle $(\mathrm{r}=.335, \mathrm{p}<0.05)$ and family and friends are significantly correlated to consumer attitude $(\mathrm{r}=.336, \mathrm{p}<0.05)$. Consumers' social class is a moderator which use in this study.

In this study $\mathrm{H} 1, \mathrm{H} 2, \mathrm{H} 3$, are accepted. Its mean consumer health, environmental consciousness and ethical consumerism are positively or significantly correlated consumer behavior and their intention to purchase eco-friendly cosmetics. 
Table 4-2. Correlation Analysis of Health consciousness and intention to buy

\begin{tabular}{|c|c|c|c|}
\hline \multicolumn{4}{|c|}{ Correlations } \\
\hline & & Health & Intention \\
\hline \multirow[t]{3}{*}{ Health } & \begin{tabular}{|l} 
Pearson \\
Correlation
\end{tabular} & 1 & $.196 * *$ \\
\hline & Sig. (2-tailed) & & .001 \\
\hline & $\mathrm{N}$ & 261 & 261 \\
\hline \multirow[t]{3}{*}{ Intention } & $\begin{array}{l}\text { Pearson } \\
\text { Correlation }\end{array}$ & $.196 * *$ & 1 \\
\hline & Sig. (2-tailed) & .001 & \\
\hline & $\mathrm{N}$ & 261 & 261 \\
\hline
\end{tabular}

Table 4-3. Correlation Analysis of Environment consciousness and intention to buy

\begin{tabular}{|c|c|c|c|}
\hline \multicolumn{4}{|c|}{ Correlations } \\
\hline & & environment & Intention \\
\hline \multirow[t]{3}{*}{$\begin{array}{l}\text { Environmen } \\
\mathrm{t}\end{array}$} & $\begin{array}{l}\text { Pearson } \\
\text { Correlation }\end{array}$ & 1 & $.322 * *$ \\
\hline & Sig. (2-tailed) & & .000 \\
\hline & $\mathrm{N}$ & 261 & 261 \\
\hline \multirow[t]{3}{*}{ Intention } & $\begin{array}{l}\text { Pearson } \\
\text { Correlation }\end{array}$ & $.322 * *$ & 1 \\
\hline & Sig. (2-tailed) & .000 & \\
\hline & $\mathrm{N}$ & 261 & 261 \\
\hline
\end{tabular}

Table 4-4. Correlation Analysis of ethical consumerism and intention to buy

\begin{tabular}{|c|c|c|c|}
\hline \multicolumn{4}{|c|}{ Correlations } \\
\hline & & Ethical & Intention \\
\hline \multirow[t]{3}{*}{ Ethical } & $\begin{array}{l}\text { Pearson } \\
\text { Correlation }\end{array}$ & 1 & $.148 *$ \\
\hline & Sig. (2-tailed) & & .017 \\
\hline & $\mathrm{N}$ & 261 & 261 \\
\hline \multirow[t]{3}{*}{ Intention } & $\begin{array}{l}\text { Pearson } \\
\text { Correlation }\end{array}$ & $.148 *$ & 1 \\
\hline & Sig. (2-tailed) & .017 & \\
\hline & $\mathrm{N}$ & 261 & 261 \\
\hline
\end{tabular}


Table 4-5. Correlation Analysis of social class and intention to buy

\begin{tabular}{|l|l|l|l|l|}
\hline \multicolumn{5}{|c|}{ Correlations } \\
\hline \multirow{5}{*}{ Lifestyle } & $\begin{array}{l}\text { Pearson } \\
\text { Correlation }\end{array}$ & 1 & $.335^{* *}$ & $.366^{* *}$ \\
\cline { 2 - 5 } & Sig. (2-tailed) & & .000 & .000 \\
\cline { 2 - 5 } & $\mathrm{N}$ & 261 & 261 & 261 \\
\hline \multirow{5}{*}{ Friends } & $\begin{array}{l}\text { Pearson } \\
\text { Correlation }\end{array}$ & $.335^{* *}$ & 1 & $.215^{* *}$ \\
\cline { 2 - 5 } & Sig. (2-tailed) & .000 & & .000 \\
\cline { 2 - 5 } & $\mathrm{N}$ & 261 & 261 & 261 \\
\hline \multirow{5}{*}{ intention } & $\begin{array}{l}\text { Pearson } \\
\text { Correlation }\end{array}$ & $.366^{* *}$ & $.215^{* *}$ & 1 \\
\cline { 2 - 5 } & Sig. (2-tailed) & .000 & .000 & \\
\cline { 2 - 5 } & $\mathrm{N}$ & 261 & 261 & 261 \\
\hline \multirow{2}{*}{ N*. Correlation is significant at the 0.01 level (2-tailed). } \\
\hline
\end{tabular}

Results show that the consumer social class (lifestyle, family and friend) significantly correlated with consumer intention to purchase eco-friendly cosmetics. Consumer values health consciousness, environmental consciousness and ethical consumerism are also significantly correlated.

\subsection{Hypothesis Testing}

4.4.1 Consumers' values (health consciousness) firmly influence consumer intentions to buy ecofriendly cosmetic

Results presents that an independent variable consumer values (health consciousness) is foreseeing $38 \%$ ( $\mathrm{R}$ square $=0.38)$ variance of dependent variable customer intention to purchase.

- Regression coefficient value means beta value of consumer values (health consciousness) is $19.6 \%$ affecting the variable which is dependent means consumer intention to purchase. So, results show that the first variable of consumer values; health consciousness have impact significantly on consumer attitude and their intention to purchase eco-friendly cosmetics.

- "P value" $(\mathrm{p}<0.05)$ shows that the hypothesis is accepted.

Table 4-6 Regression analysis of health consciousness and consumer intentions

\begin{tabular}{|l|l|l|}
\hline & Values & Beta Value \\
\hline R square & .384 & \\
\hline Adj. R square & .352 & \\
\hline Sig. & .001 & \\
\hline Health consciousness & & 0.196 \\
\hline
\end{tabular}

Coefficient determination which depicted through "R square" is the measure which examines the \% of variance produced towards dependent variable aside variable which is independent. "R square" describe about model is well suited or not. Value of Beta describe that how much intensity of independent variable influence dependent variable. But if beta value has negative sign its means a negative and weak relationship between the variables. Further, if significant value is "smaller than $0.05(\mathrm{p}<0.05)$ " means accept the hypothesis of study. 


\subsubsection{Consumers' values (environmental consciousness) firmly influence consumer intentions to buy eco-friendly cosmetic}

After health consciousness analyze other variable of consumer values (environmental consciousness) is foreseeing $(\mathrm{R}$ square $=.104)$ variance in consumer intentions.

- Beta value of environmental consciousness is $32.2 \%$ influencing the consumer attitude toward intention to purchase eco-friendly cosmetics. So, health consciousness positively influences consumer attitude to purchase eco-friendly cosmetics.

- Further significance level presents that this hypothesis too accepted " $p<0.05$ ".

Table 4.7. Regression analysis of environment consciousness and consumer intentions.

\begin{tabular}{|l|l|l|}
\hline & Values & Beta \\
\hline R square & .104 & \\
\hline Adj. R square & .100 & \\
\hline Sig. & 0.00 & \\
\hline Environment consciousness & & 0.322 \\
\hline
\end{tabular}

\subsubsection{Consumer values (ethical consumerism) firmly influence consumer intentions to buy eco-} friendly cosmetics.

In last of the consumer values analyze the ethical consumerism of consumer and according to results ethical consumerism is foreseeing $(\mathrm{R}$ square $=.022)$ variance in consumer intentions.

- Beta value of ethical consumerism is 3.29 influencing the consumer attitude toward intention to purchase eco-friendly cosmetics. So, ethical consumerism positively influence consumer attitude to purchase eco-friendly cosmetics.

- Further significance value presents that this hypothesis also accepted " $p<0.05$ ".

Table 4-8. Regression analysis of ethical consumerism and consumer intentions

\begin{tabular}{|l|l|l|}
\hline & Values & Values of Beta \\
\hline R square & .022 & \\
\hline Adj. R square & .018 & \\
\hline Sig. & 0.01 & \\
\hline Ethical consumerism & & 3.29 \\
\hline
\end{tabular}

\subsubsection{Consumer social class firmly influence consumer intentions to buy eco-friendly cosmetics}

Results present that consumer social class is foreseeing $(\mathrm{R}$ square $=0.126)$ variance in consumer intentions. In consumer, social class life style and family and friend's variables is predicted.

Regression coefficient value of consumer social class is 0.35 effecting to dependent variable which is consumer intentions to buy. According to these results consumers social class like their lifestyle and consumer intentions significantly influence people or consumer to purchase eco-friendly products. $\mathrm{P}$ value present that the hypothesis $(\mathrm{p}<0.05)$ is accepted. Betas value presents that how independent variable and moderating variable influence consumer to purchase that type of product or not. 
Table 4-9 Regression analysis of social class and consumer intentions to buy

\begin{tabular}{|l|l|l|}
\hline & Values & Values of Beta \\
\hline R square & .126 & \\
\hline Adj. R square & .123 & \\
\hline Sig. & 0.00 & \\
\hline Social Class & & .355 \\
\hline
\end{tabular}

\section{Conclusion and Implications}

Main Purpose of this study is to analyse consumer intention to purchase toward eco-friendly cosmetics. Firstly, measured consumer values health consciousness, environmental consciousness and ethical consumerism toward intention to purchase eco-friendly cosmetics. Eco-friendly cosmetics or products is the less research area, so the constructs are choosing from distinct studies of eco-friendly, green and organic products. Secondly, social class of consumer measured as a moderator which strongly influence consumer to purchase eco-friendly products. All hypothesis was tested through SPSS 22.0 further model measurement through Amos 20.0.

Results present that the consumer values health consciousness, environmental consciousness and ethical consumerism are important factor which influence consumer to purchase eco-friendly products. Demographics of this study revealed that the data are collected from the youngsters who are more conscious toward environment and their health also. However, consumers who are more conscious about health and environment more purchase eco-friendly products.

In this research inspect the moderating impact or influence of consumer social class on relationship between consumer values toward buying eco-friendly cosmetics and intention to purchase. Further findings present that the moderating variable social class significantly influence consumer intentions to purchase eco-friendly cosmetic. Findings present that not only consumer values which affect consumer intention to purchase but social pressure is also very significant or important factor which modify the behavior of consumer. Eco-friendly products are costly as compare to traditional products so the social class of consumer is very important for study related to eco-friendly, organic and green products. Planned behavior theory found to a significant theory not only in organic cosmetics or food but also in ecofriendly cosmetics.

\subsection{Academic Implications}

Academically the contribution of this study is related toa few researches among in world which take into consideration towards a significant issue of eco-friendly cosmetics. Further this study measure consumer social class towards intention to purchase. Theory of planed behavior also use and examine its impact on consumer intention to purchase. So, this research fills the gap of literature.

\subsection{Managerial Implications}

This study will make a valuable contribution in the field of eco-friendly cosmetic industry. It will provide benefit to marketer of cosmetic industry in understanding that how customer values and their social class impacts on their purchasing behavior. Now this is important for eco-friendly and other cosmetics organizations to create a greater recognition among consumers. So, marketing manager of these organizations start different campaigns and sale promotion techniques for motivate consumers to purchase that product.It is crucial for beauty care and cosmetic executives to establish a deeper awareness into the elements which influencing the purchasing behavior of consumers toward eco-friendly cosmetics and other beauty related products in Pakistan. Sharmila, Thanika and Yogini (2016) investigate that the female consumers possess distinct level of significant to the diverse dimensions which turn to contribute their buying pattern as eco-friendly cosmetics and other green or beauty related products. Further this study represents interesting perceptions on consumers self-image, health, life style and economic considerations 
are the rising predictors regarding preference of eco-friendly and other beauty related cosmetics. Thus, the current research has diverse implications for eco-friendly cosmetics or green cosmetic executives. This data is very useable for Pakistani industries because in current era customers are more awake and they will judgetwice or more before taking the decision to purchase any type of eco-friendly products because these products are costly.Eco-friendly Marketing is not just the strategy but necessity. Let's make a start!

\subsection{Recommendations}

Cosmetics industry is that industry which indulging the interest of all age, Sex and season. New born to golden age all have desire to look young plus attractive also. Further the changing of economic conditions and due to demographic surroundings people are aware to spend their major part of income toward cosmetics. Consumer or people are also conscious to purchase that cosmetics which are not harm for environment and mother earth because people are aware regarding the pollution of environment which increase day by day. These types of consumers or people attitude require, being focus by eco-friendly marketers. Many researchers result mention that, people lacks awareness toward eco-friendly cosmetics is the major issue before the enforcement of eco-friendly products and cosmetics. According to this research results mostly people are aware to eco-friendly cosmetics and use also these products. So, this is important for government to establish the rules which protect our environment and the natural resources also. Marketers of these products grip this opportunity, because many segments already present the pragmatic attitude toward planets and their environment.

\section{References}

Ahmad, N., Omar, A., \&Ramayah, T. (2014). A lifestyles study on purchasing behavior of Malaysian online consumers.

Ajzen, I. (1991). The theory of planned behavior. Organizational behavior and human decision processes, 50(2), 179-211.

Ajzen, I., 1985. From intentions to actions: a theory of planned behavior. In: Kuhl, J., Beckman, J. (Eds.), Action Control: From Cognition to Behavior. Springer, Heidelberg.

Akehurst G, Afonso C, Gonçalves HM. Re-examining green purchase behaviour and the green consumer profile: new evidences. ManagDecis 2012; 50(5): 972 - 988

Al-Swidi, A., RafiulHuque, S.M., Hafeez, M.H., Mohd Shariff, M.N., 2014. The role of subjective norms in theory of planned behavior in the context of organic food consumption. Br. Food J. 116 (10), 1561-1580.

Auger, P. and Devinney, T.M. (2007), "Do what consumers say matter? The misalignment of references with unconstrained ethical intentions", Journal of Business Ethics, Vol. 76 No. 4, pp. 361-438

B. Godey, D. Pederzoli, G. Aiello, R. Donvito, P. Chan, H. Oh, and B. Weitz, "Brand and country-oforigin effect on consumers' decision to purchase luxury products," Journal of Business Research, vol. 65, no. 10, pp. 1461-1470, 2012

B. Ranjbarian, A. Sanayei, and M. R. Kaboli, "An analysis of brand image, perceived quality, customer satisfaction and re-purchase intention in Iranian department stores," International Journal of Business and Management, vol. 7, no. 6, pp. 40-48, 2012.

Bagozzi, Richard P. Joham Baumgartner, and Youjae Yi 1988. "An Investigation into the Role of Volitions as Intervening Variables in the Atitude-Behavior Relationship." Unpublished working paper, The University of Michigan.

Bang, H.K., Ellinger, A.R., Hadjimarcou, J. and Traichal, P.A. (2000), "Consumer concern, knowledge, belief, and attitude toward renewable energy: an application of the reasoned action theory", Psychology and Marketing, Vol. 17 No. 6, pp. 449-468.

Banyte J, Brazioniene L, Gadeikiene A. Expression of green marketing developing the conception of corporate social responsibility. InzinerineEkonomika-Engineering Economics. 2010; 21(5): 550560.

Barber, N. A., Bishop, M., Gruen, T. 2014. Who pays more (or less) for pro-environmental consumer goods? Using the auction method to assess actual willingness-to-pay Journal of Environmental Psychology 40, 218-227 
Biswas, A. and Roy, M. 2015. Green Products: An Exploratory Study on the Consumer Behaviour in Emerging Economies of the East. J. Clean. behav, 87, 462-468.

Carrete, L., Castaño, R., Felix, R., Centeno, E., \& González, E. (2012). Green consumer behavior in an emerging economy: confusion, credibility, and compatibility. Journal of consumermarketing, 29(7), 470-481

Cervellon, M-C, Wernerfelt, A-C. 2012. Knowledge sharing among green fashion communities online. Journal of Fashion Marketing and Management: An International Journal 16 (2), 176 - 192

Chan, R.Y.K, Leung, T.K.P. and Wong, Y.H. (2006), "The effectiveness of environmental claims for services advertising", Journal of Services Marketing, Vol. 20 No. 4, pp. 233-250

Chanaron, J.-J. (2013). Innovative lifestyle: towards the life of future-an exploratory essay. Megatrend revija, 10(1), 63-82.

Chase, D. (1991), "The green revolution: P\&G gets top marks in AA survey", Advertising Age, Vol. 62 No. 5, pp. 8-10.

Chen, M.F., 2016. Extending the theory of planned behavior model to explain people's energy savings and carbon reduction behavioral intentions to mitigate climate change in Taiwan-moral obligation matters. J. Clean. Prod. 112 (2), 1746-1753

Chen, T.B. and Chai, L.T. (2010), "Attitude towards the environment and green products: consumers perspective", Management and Science Engineering, Vol. 4 No. 2, pp. 27-39.

Chin, H.C., Choong, W.W., Alwi, S.R.W., Mohammed, A.H., 2016. Using theory of planned behaviour to explore oil palm smallholder planters' intention to supply oil palm residues. J. Clean. Prod. 126, 428-439.

Chumpitaz, R. and Paparoidamis, N.G. (2004), "Service quality and marketing performance in businessto-business markets: exploring the mediating role of client satisfaction", Managing ServiceQuality, Vol. 14 No. 2, pp. 235-248.

Churchill, G.A., Jr (1979), “A paradigm for developing better measures of marketing constructs”, Journal of Marketing Research, Vol. 16 No. 1, p. 64.

Conner, M. and Armitage, C. (1998), "Extending the theory of planned behavior: a review and avenues for further research", Journal of Applied Social Psychology, Vol. 28 No. 15, pp. 1429-64.

Coddington, W. (1993), Environmental Marketing: Positive Strategies for Reaching the Green Consumer, McGraw-Hill Inc, New York, NY.

Cornelissen, G., Pandelaere, M., Warlop, K. and Dewitte, S. (2008), "Positive cueing: promoting sustainable consumer behaviour by cueing common environmental behaviours as environmental", International Journal of Research in Marketing, Vol. 25 No. 1, pp. 46-55.

D. Brécard, B. Hlaimi, S. Lucas, Y. Perraudeau, and F. Salladarré, "Determinants of demand for green products: An application to eco-label demand for fish in Europe," Ecological Economics, vol. 69, no. 1 , pp. 115-125, 2009

D’Souza, C., Taghian, M. and Khosla, R. (2007b), "Examination of environmental beliefs and its impact on the influence of price, quality and demographic characteristics with respect to green purchase intention", Journal of Targeting, Measurement and Analysis for Marketing, Vol. 15 No. 2, pp. 6978.

Davies, I.A., Lee, Z., Ahonkhai, I., 2012. Do consumers care about ethical-luxury? J. Bus. Ethics 106 (1), $37 \mathrm{e} 51$

De Maya, S. R., López-López, I., Munuera, J.L. 2011. Organic food consumption in Europe: International segmentation based on value system differences Ecological Economics 70 1767-1775

Dembkowski, S. (1998), "The environmental value-attitudesystem model: understanding the divergence between stated environmental consciousness and overt consumer behaviour", Eco-management and Auditing, Vol. 5 No. 2, pp. 62-74.

Diamantopoulos, A., Schlegelmilchh, B.B., Sinkovics, R.R. and Bohlen, G.B. (2003), "Can socio demographics still play a role in profiling green consumers? A review of the evidence and an empirical investigation", Journal of Business Research, Vol. 56 No. 6, pp. 465-480.

Do Paço, A.M.F., Raposo, M.L.B. and Filho, W.L. (2009), "Identifying the green consumer: a segmentation study", Journal of Targeting, Measurement and Analysis for Marketing, Vol. 17 No. 
1, pp. 17-25.

Dwyer, R.J., 2009. Keen to be green organizations: a focused rules approach to accountability. Manag. Decis. 47 (7), 1200-1216.

Ecocert (2003) was the very first certification body to develop standards for "natural and organic cosmetics" www.ecocert.com Introduced in 2003. Retrieved on 18th Sep 11

Elliott, R., 2013. The taste for green: the possibilities and dynamics of status differentiation through “green”, consumption. Poetics 41, 294e322.

Essoussi, L., Zahaf, M., 2008. Decision making process of community organic food consumers: an exploratory study. J. Consum. Mark. 25, 95e104.

Feather, N. (1990), "Bridging the gap between values and actions: recent applications of the expectancyvalue model", in Higgins, E. and Sorrentino, R. (Eds), Handbook of Motivation and Cognition: Foundations of Social Behavior, Guilford Press, New York, NY, pp. 151-92

Ferrer, A., Hidalgo, C., Kaps, R., Kougoulis, J.S., 2012. Revision of European Ecolabel Criteria for Soaps, Shampoos and Hair Conditioners: Market Analysis. Retrieved from: http://susproc.jrc.ec.europa.eu/soaps_and_shampoos/docs/Technical\%20background\%20draft\%20 report.pdf.

Fraj, E., \& Martinez, E. (2006a). Environmental values and lifestyles as determining factors of ecological consumer behaviour: an empirical analysis. Journal of consumer marketing, 23(3), 133-144.

Fraj, E., \& Martinez, E. (2006b). Influence of personality on ecological consumer behaviour. Journal of Consumer Behaviour, 5(3), 167-181.

Fryxell, G. and Lo, C. (2003), "The influence on environmental knowledge and values on managerial behaviours on behalf of the environment: an empirical examination of managers in China", Journal of Business Ethics, Vol. 46 No. 1, pp. 45-59.

Gan, C., Wee, H.Y., Ozanne, L. and Kao, T.H. (2008), “Consumers' purchasing behaviour towards green products in New Zealand”, Innovative Marketing, Vol. 4 No. 1, pp. 93-102.

Gracia, A., and Magistris, T. 2007. Organic food product purchase behaviour: a pilot study for urban consumers in the South of Italy. Spanish Journal of Agriculture Research 5(4), 439-451.

Grankvist, G. And Biel, A. 2007. Predictors of purchase of eco-labelled food products: A panel study Food Quality and Preference 18, 701-708

Griskeicius, V., Tybur, J.M., Van den Bergh, B., 2010. Going green to be seen: Status, reputation, and conspicuous conservation. Interpersonal Relations and Gro. Proc. 98 (3), 392-404.

Grunert, S. and Juhl, H.J. (1995), "Values, environmental attitudes, and buying of organic foods", Journal of Economic Psychology, Vol. 17 No. 1, pp. 39-62.

Haden, S.S.P., 2009. Historical, practical, and the theoretical perspectives on green management: an exploratory analysis. Manag. Decis. 47 (7), 1041-1055.

Hair, J.F. Jr, Anderson, R.E., Tatham, R.L. and Black, W.C. (2007), Multivariate Data Analysis, 6th ed., Prentice-Hall, Englewood Cliffs, NJ.

Han, H., Kim, Y., 2010. An investigation of green hotel customers' decision formation: developing an extended model of the theory of planned behavior. Int. J. Hosp.Manag. 29 (4), 659-668.

Hee Yeon Kim and Jae-Eun Chung Department of Consumer Sciences, The Ohio State University, Columbus, Ohio, USA (2011).

Hsu, C.-L., Chang, C.-Y., Yansritakul, C., 2017. Exploring purchase intention of green skincare products using the theory of planned behaviour: testing the moderating effects of country of origin and price sensitivity. J. Retail. Consum. Serv. 34, 145e152.

J. C. P. Su, L. Wang, and J. C. Ho, "The impacts of technology evolution on market structure for green products," Mathematical and Computer Modelling, vol. 55, no. 3, pp. 1381-1400, 2012.

Jansson, J., Marell, A., Nordlund, A., 2010. Green consumer behaviour: determinants of curtailment and eco-innovation adoption. Journal of Consumer Marketing 27, 358-370.

Jayanti, R. K., \& Burns, A. C. (1998). The antecedents of preventive health care behavior: An empirical study. Journal of the academy of marketing science, 26(1), 6-15.

Johri, L.M. and Sahasakmontri, K. (1998), "Green marketing of cosmetics and toiletries in Thailand", Journal of Consumer Marketing, Vol. 15 No. 3, pp. 265-281. 
Kalafatis, S.P., Pollard, M., East, R., Tsogas, M.H., 1999. Green marketing and Ajzen's theory of planned behavior: a cross-market examination. Journal of Consumer Marketing 16 (5), 441-460.

Kalita, M., 2014. Eco-friendly buying behaviour of women: a study with special reference to Guwahati city, India. Clar. 3, 124e128.

Kaynak, E., Kara, A., (2002). Consumer perceptions of foreign prod- ucts. An analysis of product-country images and ethnocentrism. European Journal of Marketing 36, 928-949.

Khare, A. (2014). Consumers' susceptibility to interpersonal influence as a determining factor of ecologically conscious behaviour. Marketing Intelligence \& Planning, 32(1), 2-20.

Kim, H., Chung, J., 2011. Consumer purchase intention for organic personal care products. J. Consum. Mark. 28, 40e47

Kim, S., Seock, Y., 2009. Impacts of health and environmental consciousness on young female consumers' attitude towards and purchase of natural beauty products. Int. J. Consum. Stud. 33, $627 \mathrm{e} 638$.

Kim, Y.J., Njite, D., Hancer, M., 2013. Anticipated emotion in consumers' intentions to select ecofriendly restaurants: augmenting the theory of planned behavior. Int. J. Hosp. Manag. 34, 255262.

Kline, R. B. (2010). Principles and practice of structural equation modeling. The Guilford Press.

Kotler, P., Armstrong, G., Saunders, J. and Wong, V. (2005), Principles of Marketing, 3rd European ed., Essec, Prentice Hall, London.

Kraft, F. B., \& Goodell, P. W. (1993). Identifying the health-conscious consumer. Marketing Health Services, 13(3), 18.

Kumar, B., Manrai, A.K., Manrai, L.A., 2017. Purchasing behaviour for environmentally sustainable products: a conceptual framework and empirical study. J. Retail. Consumer. Serv. 34, 9

L. J. Shrum, J. A. McCarty, and T. M. Lowrey, "Buyer characteristics of the green consumer and their implications for advertising strategy," Journal of Advertising, vol. 24, no. 2, pp. 71-82, 1995.

Laheri VK, Dangi H, Vohra A (2014) Green marketing: development of construct and its evolution. AsiaPacific Journal of Management Research and Innovation 10:147-155

Laroche, M., Bergeron, J. and Barbaro-Forleo, G. (2002), "Cultural differences in environmental knowledge, attitudes, and behaviours of Canadian consumers", Canadian Journal of Administrative Sciences, Vol. 19 No. 3, pp. 267-283

Laroche, M., Bergeron, J., Barbaro-Forleo, G., 2001. Targeting consumers who are willing to pay more for environmentally friendly products. Journal of Consumer Marketing 18 (6), 503-520

Lee, H.J.; H. Lim; L.D. Jolly; and J. Lee. (2009). Consumer lifestyles and adoption of hightechnology products: A case of South Korea, Journal of International Consumer Marketing 21(3), 153-167.

Manaktola, K. and Jauhari, V. (2007), "Exploring consumer attitude and behaviour towards green practices in the lodging industry in India", International Journal of Contemporary Hospitality Management, Vol. 19 No. 5, pp. 364-377

Maniatis, P., 2016. Investigating factors influencing consumer decision-making while choosing green products. J. Clean. Prod. 132, 215-228.

Martenson, R. (2007), "Corporate brand image, satisfaction and store loyalty: a study of the store as a brand, store brands and manufacturer brands", International Journal of Retail \& DistributionManagement, Vol. 35 No. 7, pp. 544-555.

Mather, D., Knight, J. and Holdworht, D. (2005), "Pricing differentials for organic, ordinary and genetically modified food", Journal of Product and Brand Management, Vol. 14 No. 6, pp. 387392.

McEachern, M.G. and McClean, P. (2005), "Organic purchasing motivations and attitudes: are they ethical?”, International Journal of Consumer Studies, Vol. 26 No. 2, pp. 85-92.

McWilliams, A. and Siegel, D. (2001), "Corporate social responsibility: a theory of the firm perspective", Academy of Management Review, Vol. 26 No. 1, pp. 117-127.

Memery, J., Megicks, P. and Williams, J. (2005), "Ethical and social responsibility issues in grocery shopping: a preliminary typology", Qualitative Market Research: An International Journal, Vol. 8 No. 4, pp. 399-412. 
Moisander, J. (2007), "Motivational complexity of green consumerism", International Journal of Consumer Studies, Vol. 31 No. 4, pp. 404-9.

Mont, O., Plepys, A., 2008. Sustainable consumption progress: should we be proud or alarmed? J. Clean. Prod. 16, 531e537.

Moser, A.K., 2016. Consumers' purchasing decisions regarding environmentally friendly products: an empirical analysis of German consumers. J. Retail. Consum. Serv. 31, 389-397.

Mostafa, M.M. (2009): Shades of Green - A Psychographic Segmentation of The Green Consumer in Kuwait Global Engineers \& Technologists Review, Vol.4 No.1 (2014) Using Self- Organizing Maps, Expert Systems with Applications, Vol.36, Iss.8, pp.11030-11038.

Moungkhem, C., Surakiatpinyo, J., 2010. A Study of Factors Affecting on Men's Skin Care Products Purchasing, Particular in Kalstad, Sweden. Kalstad University, Kalstad.

Michaelidou, N. and Hassan, L.M. (2008), "The role of health consciousness, food safety concern, and ethical identity on attitudes and intentions towards organic food", International Journal of Consumer Studies, Vol. 32 No. 2, pp. 163-70.

Narang, R. (2010). Psychographic segmentation of youth in the evolving Indian retail market. The International review of retail, distribution and consumer research, 20(5), 535-557.

Newsom, J., Mcfarland, B., Kaplan, M., Huguet, N. and Zani, B. (2005), "The health consciousness myth: implications of the near independence of major health behaviors in the North American population", Social Science \& Medicine, Vol. 60 No. 2, pp. 433-437.

Newsom, J., McFarland, B., Kaplan, M., Huguet, N. and Zani, B. (2005), "The health consciousness myth: implications of the near independence of major health behaviors in the North American population", Social Science \& Medicine, Vol. 60 No. 2, pp. 433-7.

Nguyen, T.N., Lobo, A., Greenland, S., 2016. Pro-environmental purchase behaviour: the role of consumers' biospheric values. J. Retail. Consum. Serv. 33, 98-108.

NorazahMohd Suki Labuan School of International Business \& Finance, University Malaysia Sabah, Labuan International Campus, Federal Territory of Labuan, Malaysia (2015)

Onwezen, M.C., Bartels, J., Antonides, G. 2014. Environmentally friendly consumer choices: Cultural differences in the selfregulatory function of anticipated pride and guilt Journal of Environmental Psychology 40, 239-248

Orth, U. R., McDaniel, M., Shellhammer, T., \&Lopetcharat, K. (2004). Promoting brand benefits: the role of consumer psychographics and lifestyle. Journal of ConsumerMarketing, 21(2), 97-108.

Ottman, A.J., Stafford, E.R. and Hartman, C.L. (2006), "Avoiding green marketing myopia: ways to improve consumer appeal for environmentally preferable products”, Environment, Vol. 48 No. 5, pp. 22-36.

Paço, A., Alves, H., Shiel, C., Leal Filho, W. 2013. Development of a green consumer behaviour model. International Journal Consumtion Studies 37, 414-421.

Paladino, A. (2005), "Understanding the green consumer: an empirical analysis", Journal of Customer Behaviour, Vol. 4 No. 1, pp. 69-102

Paladino, A. (2006), "Understanding the green consumerism: an empirical analysis", Journal of Customer Behaviour, Vol. 4 No. 1, pp. 69-102.

Paul, J., Modi, A., Patel, J., 2016. Predicting green product consumption using theory of planned behavior and reasoned action. J. Retail. Consum. Serv. 29, 123-134.

Pearson, D., Henryks, J., 2008. Marketing organic products: exploring some of the pervasive issues. J. Food Prod. Mark. 14 (4), 95e108.

Peattie, K. (2001), “Golden goose or wild goose? The hunt for the green consumer", Business Strategy and the Environment, Vol. 10 No. 4, pp. 187-99.

Peattie, K., Peattie, S. and Ponting, C. (2009), "Climate change: a social and commercial marketing communications challenge”, EuroMed Journal of Business, Vol. 4 No. 3, pp. 270-286.

Pervin, S., Ranchhod, A., Wilman, M., 2014. Trends in cosmetics purchase: ethical perceptions of consumers in different cultures. A cross country comparative study between South Asian and Western consumers. J. Consum. Behav. 13 (1), $57 \mathrm{e} 72$.

Peter, J.P. and Olson, J.C.(2009) Consumer Behaviour and Marketing Strategy, McGraw Hill. Paladino, 
A. (2006), "Understanding the green consumerism: an empirical analysis", Journal of Customer Behaviour, Vol. 4 No. 1, pp. 69-102.

Pickett-Baker, J. and Ozaki, R. (2008), "Pro-environmental products: marketing influence on consumer purchase decision", Journal of Consumer Marketing, Vol. 25 No. 5, pp. 281-293

Pizam, A., 2009. Green hotels: a fad, ploy or fact of life? International Journal of Hospitality Management 28 (1) (editorial).

Polonsky, M. and Mintu-Wimsatt, A. (1995), Environmental Marketing, The Haworth Press, New York, NY.

Poortinga, W., Stec, L. and Vlek, C. (2004), "Values, environmental concern, and environmental behavior", Environment and Behavior, Vol. 36 No. 1, pp. 70-93.

Prothero, A. and McDonagh, P. (1992), "Producing environmentally acceptable cosmetics? The impact of environmentalism on the United Kingdom cosmetics and toiletries industry", Journal of Marketing Management, Vol. 8 No. 2, pp. 147-66.

Rios, F., Martinez, T., Moreno, F. and Soriano, P. (2006), "Improving attitudes toward brands with environmental associations: an experimental approach", The Journal of Consumer Marketing, Vol. 23 No. 1, pp. 26-34.

Ritter, A.M., Borchardt, M., Vaccaro, G.L.R, Pereira, G.M., Almeida, F., 2015. Motivations for promoting the consumption of green products in an emerging country: exploring attitudes of Brazilian consumers. J. Clean. Prod. 106, 507e520.

Roberts JA, Bacon DR. Exploring the subtle relationships between environmental concern and ecologically conscious behavior. J Bus Res 1997; 40(1):79 - 89.

Rokeach, M. (1973), The Nature of Human Values, Free Press, New York, NY

Said, A.M., Ahmadun, F.R., Paim, L.H. and Masud, J. (2003), "Environmental concerns, knowledge and practices gap among Malaysian teachers", International Journal Sustainability Higher Education, Vol. 4 No. 4, pp. 305-313.

Schwartz, S. and Blisky, W. (1987), “Toward universal psychological structure of human values”, Journal of Personality and Social Psychology, Vol. 53 No. 3, pp. 550-62.

Sharmila Pudaruth, Thanika Devi Juwaheer and Yogini Devi Seewoo (2016) Journal of eco-friendly cosmetics.

Suki NM, Suki NM (2015a) Consumption values and consumer environmental concern regarding green products. Int J Sust Dev World. 1-10

Smith, S., \& Paladino, A. (2010). Eating clean and green? Investigating consumer motivations towards the purchase of organic food. Australasian Marketing Journal (AMJ), 18(2), 93-104.

Solomon, M. R., G. Bamossy, S. Askegaard, and M. K. Hogg (2010). Consumer Behaviour: A European Perspective. 4th edition. New York: Prentice Hall.

Steenkamp, J-B EM and Baumgartner, H. (1998) 'Assessing measurement invariance in cross-national consumer research', Journal of Consumer Research 25: 78-90.

Stern, P. C., Dietz, T., Kalof, L. 1993. Value orientations, gender, and environmental concern. Environment and Behavior, 322-348

Schifferstein, H. N., \&Ophuis, P. A. O. (1998). Health-related determinants of organic food consumption in the Netherlands. Food quality and Preference, 9(3), 119-133.

Tamashiro, H.R.S., Silveira, J.A.G., Merlo, E.M., Acevedo, C.A., 2014. Structural equation modelling applied to a study on the background of green buying behaviors. PARIPEX Indian J. Res. 3 (9), $1 \mathrm{e} 8$.

Tarkiainen, A., Sundqvist, S., 2005.Subjective norms, attitudes and intentions of Finnish consumers in buying organic food. Br. Food J. 107 (11), 808-822.

Teng YM, KS W, Liu HH (2013) Integrating altruism and the theory of planned behaviour to predict patronage intention of a green hotel. J Hosp Tour Res 37:1-18

Thompson, A.M. and Kaminski, P.F. (1993), "Psychographic and lifestyle antecedents of servicequality expectations: a segmentation approach", The Journal of Service Marketing, Vol. 7 No. 4, pp. 5361.

Tirone, A. (2007), "Natural \& body care driver's growth, inside cosmeceuticals", available at: 
www.insidecosmeceuticals.com/articles/2007/10/natural-body-care-drivers-growth.aspx (accessed 5 September 2013).

Todd, A.M. (2004), “The aesthetic turn in green marketing”, Ethics \& The Environment, Vol. 9 No. 2, pp. 86-102.

Tsakiridou, E., Boutsouki, C., Zotos, Y. and Mattas, K. (2008), "Attitudes and behavior towards organic products: an exploratory study", International Journal of Retail \& Distribution Management, Vol. 36 No. 2, pp. 158-175.

Tukker, A., Cohen, M.J., Hubacek, K., Mont, O., 2010. Sustainable consumption and production. J. Ind. Ecol. 14 (1)

Van Loo, E.J., Diem, M.N.H., Pieniak, Z., Verbeke, W., 2013. Consumer attitudes, knowledge, and consumption of organic yogurt. J. Dairy Sci. 96 (4), 2118-2129.

Vermeir, I., Verbeke, W. 2008. Sustainable food consumption among young adults in Belgium: Theory of planned behavior and the role of confidence and values. Ecological economics 64, 542-553.

Wagner SA. Understanding green consumer behavior. London: Routledge; 1997.

Wier, M., Jensen, K.O., Andersen, L.M., Millock, K., 2008. The character of demand in mature organic food markets: Great Britain and Denmark compared. Food Policy 33 (5), 406-421.

Wiid. J.and Diggins .C (2009). Marketing Research. Cape Town: Juta and Company.

Xie, B., Wang, L., Yang, H., Wang, Y., Zhang, M., 2015. Consumer perceptions and attitudes of organic food products in Eastern China. Br. Food J. 117 (3), 1105-1121.

Yadav, S., \& Siraj, S. (2016). Youth shoppers-study of psychographics, motives and shopping behaviour. International Journal of Indian Culture and Business Management, 12(3), 342-360.

Yiridoe, E.K., Bonti-Ankomah, S. and Martin, R.C. (2005), "Comparison of consumer perceptions and preferences toward organic versus conventionally produced foods: a review and update of the literature", Renewable Agriculture and Food Systems, Vol. 20 No. 4, pp. 193-205.

Yu, C.-S. (2011), "Construction and validation of an e-lifestyle instrument", Internet Research, Vol. 21 No. 3, pp. 214-235

Zanoli, R. and Naspetti, S. (2002), "Consumer motivations in the purchase of organic food. A means-end approach", British Food Journal, Vol. 104 No. 8, pp. 643-653.

Zeithaml, V.A. (1988), "Consumer perceptions of price, quality, and value: a means-end model and synthesis of evidence", Journal of Marketing, Vol. 52 No. 3, pp. 2-22.

Zhao, H-H., Gao, Q., Wu, Y-P., Wang, Y., Zhu, X-D. 2014. What affects green consumer behavior in China? A case study from Qingdao. Journal of Cleaner Production 63, 143-151.

Zimmer MR, Stafford TF, Stafford MR. Green issues: dimensions of environmental concern. J Bus Res 1994; 30(1):63 - 74 . 